\title{
ZMIANY W ZASOBACH I JAKOŚCI KAPITAŁU LUDZKIEGO NA OBSZARACH WIEJSKICH POLSKI I WSCHODNICH NIEMIEC
}

\author{
CHANGES IN RESOURCES AND QUALITY OF HUMAN \\ CAPITAL IN RURAL AREAS OF POLAND AND EAST GERMANY
}

\author{
Aleksandra JEZIERSKA-THÖLE \\ Uniwersytet Mikołaja Kopernika \\ Katedra Gospodarki Przestrzenne i Turyzmu \\ ul. Lwowska 1, 87-100 Toruń \\ alekjez@umk.pl
}

\begin{abstract}
Zarys treści: Celem artykułu jest przedstawienie zmian w zasobach kapitału ludzkiego na obszarach wiejskich Polski i wschodnich Niemiec. Wskazano, że finansowanie UE może być jednym z czynników zmniejszających zdiagnozowane problemy demograficzne. Przedstawiono genezę badań nad kapitałem ludzkim jako jednym z najważniejszych zasobów ekonomicznych. W tym celu dokonano przeglądu teorii ekonomicznych z uwzględnieniem miejsca i roli kapitału ludzkiego w rozwoju społeczno-ekonomicznym kraju i regionu. Obszarem badań była Polska północna i zachodnia oraz wschodnie Niemcy. Do oceny jakości i ilości kapitału ludzkiego przyjęto elementy demograficzne (przyrost naturalny, migracje) oraz społeczne (współczynnik obciążenia ekonomicznego, bezrobocie). Przeprowadzone badania pozwoliły na wyłonienie na obszarach wiejskich obszarów wzrostu kapitału ludzkiego oraz potencjalnych obszarów problemowych.
\end{abstract}

Słowa kluczowe: kapitał ludzki, przyrost naturalny, migracje, bezrobocie, obszary wiejskie, Polska, Niemcy wschodnie.

\section{Wprowadzenie}

Współczesne przekształcenia struktur społeczno-gospodarczych Polski, będące następstwem transformacji ustrojowej oraz integracji Polski z Unią Europejską, przyczyniły się w sposób znaczący m.in. do zmian demograficznych na obszarach wiejskich. Do najważniejszych przemian zalicza się m.in. procesy migracji ludności ze wsi do miast. Migracja obejmuje przede wszystkim ludzi młodych, w wieku produkcyjnym, z wykształceniem co najmniej średnim (Jezierska-Thöle i Goraj 2013). Na skutek odpływu ludności do miast dochodzi do pogłębienia się procesów depopulacji obszarów wiejskich oraz starzenia się społeczności wiejskiej, a w konsekwencji marginalizacji wsi. W efekcie narastania tych procesów dochodzi do zmian w wielu wymiarach, w tym m.in. deprecjacji wartości kapitału 
ludzkiego (Ekins i in. 2009; Stanny 2011). Niekorzystne warunki rozwoju kapitału ludzkiego na obszarach wiejskich przyczyniają się do pogłębiania dysproporcji w poziomie rozwoju społeczno-gospodarczego między miastem a wsią. Jednocześnie zmiana priorytetów w rozwoju obszarów wiejskich, tj. odejście od pojmowania obszaru wiejskiego w kategoriach agrocentrycznych, a wzmocnienie procesów deagraryzacji wsi i rozwój pozarolniczych funkcji wymaga dywersyfikacji aktywności ekonomicznej ludności wiejskiej (Poczta i in. 2007; Heffner 2013). W obliczu rozwoju wielofunkcyjnego wsi zwiększa się rola kapitału ludzkiego zarówno jego ilości, jak i jakości przy wyznaczaniu strategii i kierunków przekształceń społeczno-gospodarczych obszarów wiejskich.

Kapitał ludzki stał się zatem istotnym elementem polityki regionalnej Unii Europejskiej, która dąży do polepszenia warunków społecznych na obszarach wiejskich, pozwala na współfinansowanie krajowych programów i projektów rozwoju regionalnego ze środków funduszy strukturalnych i Europejskiego Funduszu Spójności (EFS). Środki z EFS mają na celu przeciwdziałać przedstawionym powyżej problemom, tj. podnieść jakość zasobów ludzkich oraz wyrównać szansę pomiędzy miastem a wsią.

\section{Cel i zakres pracy}

Głównym celem opracowania było przedstawienie zmian w zasobach kapitału ludzkiego na obszarach wiejskich Polski i wschodnich Niemiec. Wskazano, że finansowanie z UE może być jednym z czynników wpływających na podniesienie jakości zasobów ludzkich na obszarach wiejskich w Polsce. Ważnym elementem opracowania jest również przedstawienie badań nad kapitałem ludzkim jako jednym z najważniejszych zasobów ekonomicznych. W tym celu dokonano przeglądu teorii ekonomicznych, z uwzględnieniem miejsca i roli kapitału ludzkiego w rozwoju społeczno-ekonomicznym kraju i regionu. Następnie opisano metody pomiaru (wynikową, kosztowną i dochodową), które umożliwiają wyodrębnienie struktury kapitału ludzkiego. Zmiany w kapitale ludzkim w Polsce północnej i zachodniej obejmującej swym zasięgiem 8 województw: warmińsko-mazurskie, kujawsko-pomorskie, wielkopolskie, pomorskie, zachodniopomorskie, lubuskie, dolnośląskie i opolskie porównano ze zmianami zachodzącymi na obszarach wiejskich w Niemczech wschodnich, charakteryzujących się podobnymi uwarunkowaniami przyrodniczymi oraz polityczno-gospodarczymi w przeszłości, odmiennymi zaś kierunkami rozwoju współcześnie. Niemcy wschodnie, obejmujące 5 krajów związkowych: Meklemburgię-Pomorze Przednie, Brandenburgię, Saksonię, Saksonię-Anhalt oraz Turyngię, objęte zostały w całości Wspólnotową Polityką Regionalną (WPR) już od 1990 r. (po zjednoczeniu Niemiec), Polska zaś od 2004 r. (po przystąpieniu do Unii Europejskiej). Takie podejście badawcze (przyjęcie jednej skali porównawczej dla Polski i Niemiec) pozwoliło na określenie dystansu w jakości zasobów ludzkich Polski i Niemiec oraz wyłonienie obszarów zajmujących w rankingu najlepsze pozycje - jako potencjalne obszary wzrostu kapitału ludzkiego oraz najsłabsze - jako potencjalne obszary problemowe. Do oceny jakości kapitału ludzkiego przyjęto elementy demograficzne (przyrost naturalny, migracje) oraz społeczne (zatrudnienie, współczynnik obciążenia ekonomicznego, bezrobocie). Analiza zmian w kapitale ludzkim dotyczyła lat 2002-2010. 


\section{Miejsce i rola kapitału ludzkiego w świetle teorii ekonomicznych}

Kapitał ludzki stał się od połowy XX w. jednym z ważniejszych przedmiotów badań w naukach ekonomicznych, geograficznych i społecznych. Przyczyniły się one do powstania licznych teorii kapitału ludzkiego, „które w większości sprowadzają się do definiowania go jako zespołu cech człowieka lub społeczeństwa, wywołujących określone skutki na poziomie mikro lub makroekonomicznym" (Kozioł 2011, s. 122). Według definicji Organizacji Współpracy Gospodarczej i Rozwoju (OECD) kapitał ludzki oznacza: wiedzę, umiejętności, kompetencje i cechy ucieleśnione w człowieku ułatwiające tworzenie indywidualnego, społecznego i gospodarczego dobrobytu (Keeley 2007). W ujęciu klasycznym pojęcie to rozumiane jest przede wszystkim jako wiedza, wykształcenie, doświadczenie, kwalifikacje i umiejętności pracowników. W bezpośredniej korelacji z kapitałem ludzkim pozostaje kapitał społeczny, który oznacza zasób informacji, kultury, wiedzy i kreatywności jednostek (Sikorska 2011). Kapitał społeczny wspiera akumulację kapitału ludzkiego. Oznacza to, że istnieje między nimi silna zależność (sprzężenie), tzn. w społeczeństwach z utrwaloną przez tradycję i kulturę skłonnością do współpracy szybciej rośnie poziom kapitału ludzkiego i tym samym tempo wzrostu gospodarczego jest wyższe (Jabłoński 2010).

W literaturze przedmiotu kapitał ludzki uważany jest za jeden z najważniejszych determinantów rozwoju społeczno-gospodarczego kraju (Domański 1998). Podobnie J. Wilkin (1998) uważa, że głównym elementem rozwoju gospodarczego i cywilizacyjnego kraju i regionu jest kapitał ludzki, a dokładnie jego poziom wykształcenia, który wpływa pozytywnie na procesy innowacyjności w gospodarce lokalnej oraz na tempo wzrostu gospodarczego. Liczne badania empiryczne w kraju: A. Sikorskiej (2011), J. Wilkina (1998), M. Stanny (2014), J. Bańskiego i K. Czapiewskiego (2008), A. Jezierskiej-Thole i M. Kluby (2011) i za granicą (Cahuc i Zylberberg 2004) wykazują, że obszary wiejskie o korzystnej strukturze demograficznej rozwijają się szybciej oraz charakteryzują się wyższym poziomem rozwoju społeczno-gospodarczego.

Wpływ kapitału ludzkiego na rozwój gospodarczy opisany został przede wszystkim w pracach G. Beckera (1975), P. Romera $(1986,1990)$ i R.E. Lucasa (1988). Do literatury przedmiotu pojęcie kapitału ludzkiego wprowadził w 1961 r. T. Schultz (laureat Nagrody Nobla z 1979), który w swoim artykule Investment in Human Capital w American Economic Review zauważył współzależność pomiędzy wzrostem ekonomicznym kraju a przyrostem kapitału ludzkiego mierzonego wielkością siły roboczej, a także poziomem kwalifikacji pracowników (Fitz-Enz 2001).

Zagadnienie kapitału ludzkiego można rozpatrywać w aspektach mikro i makroekonomicznym. W ujęciu makroekonomicznym rozumiane jest jako „czynnik rozwoju i wzrostu społeczno-gospodarczego oraz element modeli wzrostu gospodarczego” (Grzywacz i Jaźwiński 2007, s. 104). W aspekcie mikroekonomicznym inwestuje się w kapitał ludzki poprzez kształcenie społeczeństwa w celu zwiększenia produktywności (Mincer 1958). Pierwsze teorie kapitału ludzkiego pojawiły się w latach 60. i 70. XX w. Zarówno T. Schultz (1961) i G. Becker (1962), jak i B. Weisbrod (1962) uważali, że inwestowanie w kapitał fizyczny (opieka zdrowia), jak i w kapitał ludzki (szkolnictwo) prowadzi do wzrostu gospodarczego, dochodów pracowników oraz postępu w medycynie. Ekonomiści B. Weisbrod (1962) i H. Uzawa (1965) zastanawiali się nad sposobami pomiarów korzyści edukacyjnych i wskazywali, że wzrost edukacji w społeczeństwie przyniesie nie tylko korzyści majątkowe, ale również wpłynie na wzrost świadomości kolejnych pokoleń (tab. 1). 
Tabela 1. Przegląd definicji i teorii kapitału ludzkiego

\begin{tabular}{|c|c|c|c|}
\hline Rok & Autor & Model/teoria & Źródło \\
\hline 1961 & T. Schultz & $\begin{array}{l}\text { Stworzył podwaliny teorii kapitału ludz- } \\
\text { kiego, traktującej jednostkę ludzką jako } \\
\text { fenomen ekonomiczny dużo bardziej } \\
\text { wielowymiarowy niż historyczny homo } \\
\text { oeconomicus. }\end{array}$ & $\begin{array}{l}\text { Investment in Human Capital, } \\
\text { American Economic Review, 1961, } \\
51, \text { s. } 1-17 .\end{array}$ \\
\hline 1962 & G. Becker & $\begin{array}{l}\text { Przedstawił teorię kapitału ludzkiego. } \\
\text { Wprowadził pojęcie inwestowania } \\
\text { w kapitał ludzki jako alokację zasobów, } \\
\text { która wpływa na wzrost dochodów } \\
\text { w przyszłości. Uważał, że na wzrost } \\
\text { gospodarczy coraz większy wpływ } \\
\text { ma wiedza. Największą uwagę poświęcił } \\
\text { inwestowaniu w kapitał ludzki poprzez } \\
\text { szkolenia w pracy, które były dla niego } \\
\text { podstawą dla zunifikowanego modelu } \\
\text { kapitału ludzkiego. }\end{array}$ & $\begin{array}{l}\text { Investment in Human Capital, A } \\
\text { Theoretical Analysis, Journal of Politi- } \\
\text { cal Economy, 1962, 70, s. 9-49. }\end{array}$ \\
\hline 1962 & B. Weisbrod & $\begin{array}{l}\text { Uważał, że inwestowanie w ludzi i edu- } \\
\text { kację umożliwia wykorzystanie postępu } \\
\text { technicznego i prowadzi do wzrostu } \\
\text { produktywności. Dodatkowo podkreślił } \\
\text { istotę edukacji dla postępu w medycy- } \\
\text { nie, a tym samym zdrowia ludności. }\end{array}$ & $\begin{array}{l}\text { Education and Investment in Human } \\
\text { Capital, Journal of Political Economy, } \\
1962,70, \text { s. 106-123. }\end{array}$ \\
\hline 1965 & H. Uzawa & $\begin{array}{l}\text { W modelu wzrostu gospodarczego } \\
\text { istotną rolę odgrywał kapitał ludzki, } \\
\text { a przede wszystkim sektor edukacji, } \\
\text { który zwiększa efektywność pracy ludzi } \\
\text { w sektorze produkcyjnym. }\end{array}$ & $\begin{array}{l}\text { Optimum Technical Change in } \\
\text { an Aggregate Model of Economic } \\
\text { Growth, International Economic } \\
\text { Review, } 1965,6,1 \text {, s. } 18-31 .\end{array}$ \\
\hline 1965 & $\begin{array}{l}\text { R. Nelson, } \\
\text { E. Phelps }\end{array}$ & $\begin{array}{l}\text { Zaprezentowali nową hipotezę obja- } \\
\text { śniającą wzrost gospodarczy. Zauważyli, } \\
\text { że tempo, z jakim zmniejsza się dystans } \\
\text { pomiędzy barierą technologiczną } \\
\text { a obecnym poziomem produktywności, } \\
\text { zależy od poziomu kapitału ludzkiego. } \\
\text { Pogląd ten zaprzeczył wcześniej- } \\
\text { szym opiniom, że kapitał ludzki jest } \\
\text { raczej argumentem funkcji produkcji } \\
\text { gospodarki. }\end{array}$ & $\begin{array}{l}\text { Investment in Humans, Technologi- } \\
\text { cal Diffusion, and Economic Growth, } \\
\text { American Economic Review 1966, } \\
\text { 56, s. 69-75. }\end{array}$ \\
\hline 1992 & $\begin{array}{l}\text { N. Mankiw, } \\
\text { D. Romeri, } \\
\text { D. Weil }\end{array}$ & $\begin{array}{l}\text { Z neoklasycznego modelu wzrostu } \\
\text { gospodarczego z kapitałem ludzkim } \\
\text { tych autorów wynika, że podniesienie } \\
\text { inwestycji w kapitał ludzki prowadzi nie } \\
\text { tylko do wzrostu zasobu tego czynnika, } \\
\text { ale także do wzrostu zasobu kapitału } \\
\text { rzeczowego. Oznacza to, że zależność } \\
\text { między akumulacją kapitału ludzkiego } \\
\text { i rzeczowego ma charakter symetrycz- } \\
\text { ny, tzn. relacja pomiędzy poziomami } \\
\text { obydwu kapitałów jest stała na ścieżce } \\
\text { zrównoważonego wzrostu. }\end{array}$ & $\begin{array}{l}\text { A Contribution to the Economic } \\
\text { Growth, Quarterly Journal of Eco- } \\
\text { nomics, } 1992,7,2 \text {, s. } 407-437 \text {. }\end{array}$ \\
\hline 2004 & $\begin{array}{l}\text { O. Galor, } \\
\text { O. Moav }\end{array}$ & $\begin{array}{l}\text { Autorzy endogenicznego modelu } \\
\text { wzrostu gospodarczego uważali, } \\
\text { że zależność między akumulacją } \\
\text { kapitału ludzkiego i rzeczowego jest } \\
\text { asymetryczna. }\end{array}$ & $\begin{array}{l}\text { From physical to human capital } \\
\text { accumulation: Inequality and the } \\
\text { process of development, Review of } \\
\text { Economic Studies, 2004, 71, 249, } \\
\text { s. } 1001-1026 .\end{array}$ \\
\hline
\end{tabular}

Źródło: opracowanie własne na podstawie: Ł. Jabłoński (2010), K. Krzyżanowska (2012), K. Cichy i K. Malaga (2006), M. Kunasz (2003) oraz literatury podanej w tabeli. 
W latach 90. XX w. nastąpił rozwój endogenicznych i neoklasycznych teorii wzrostu gospodarczego, z których jasno wynikało, że kapitał ludzki jest głównym czynnikiem wzrostu gospodarczego współczesnego świata. W modelach N. Mankiw’a, i in. (1992) oraz O. Galor’a i O. Moav’a (2004) wyłonił się istotny wpływ kapitału ludzkiego na akumulację kapitału rzeczowego, co oznaczało ich wzajemną komplementarność i nierozerwalność. Różnice widoczne natomiast są w podejściu do zależności pomiędzy kapitałem ludzkim a kapitałem rzeczowym. W neoklasycznym modelu wzrostu gospodarczego N. Mankiw’a i in. (1992) zależność między kapitałem ludzkim i rzeczowym miała charakter symetryczny, zaś w modelu O. Galora i O. Moava (2004) asymetryczny, co oznacza, że w gospodarce znajdującej się na wyższym etapie rozwoju ekonomicznego rośnie zapotrzebowanie na kapitał ludzki, a maleje na kapitał rzeczowy (Jabłoński 2010; Cichy i Malaga 2006). Współcześnie rewolucja technologiczna związana z przetwarzaniem informacji i komunikacji wpłynęła na powstanie nowych organizacji społeczeństw i sposobów funkcjonowania jednostek. R. Nelson (2009) zwrócił uwagę na związek między postępem technologicznym i rozwojem ekonomicznym a kapitałem ludzkim. Uważał on, że kapitał ludzki odgrywa kluczową rolę w procesie adaptacji innowacji produkcyjnych. Warunkiem postępu jest zatem odpowiednie przygotowanie edukacyjne.

Z przedstawionych powyżej modeli i teorii wynika, że kapitał ludzki jest najważniejszym, obok kapitału ekonomicznego, czynnikiem wzrostu gospodarczego. Wnioski wynikające z teorii i paradygmatów kapitału ludzkiego stanowią zatem istotny element do tworzenia współczesnej polityki Unii Europejskiej oraz prowadzenia debaty publicznej. Wyrazem tego są liczne programy Unii Europejskiej i sposoby finansowania rozwoju kapitału ludzkiego.

\section{Pomiar kapitału ludzkiego i społecznego}

W badaniach empirycznych nad kapitałem społecznym wyróżnia się odmienne metody pomiaru w zależności od podejścia mikro i makroekonomicznego. W podejściu mikroekonomicznym kapitał ludzki tworzą cechy pojedynczych osób, w podejściu makro jego poziom rozpatrywany jest w ujęciu ponadjednostkowym, np. w postaci zagregowanej do gospodarstw domowych i rolnych, zakładów pracy, instytucji publicznych, organizacji pozarządowych oraz jednostek geograficznych (gmina, kraj). Zarówno w podejściu mikro, jak i makroekonomicznym stosuje się szereg cech społeczno-demograficznych reprezentujących kapitał ludzki (tab. 2). W konwencjonalnym sposobie pomiaru wyróżnia się trzy metody: wynikową, kosztową i dochodową (Kwon 2009). Metoda wynikowa określa najważniejsze cechy społeczno-ekonomiczne, takie jak: wiek, poziom wykształcenia, stan zdrowia oraz umiejętności społeczne. Podejście kosztowe dotyczy indywidualnych wydatków poniesionych na kształcenie, zdrowie i usługi. Przy pomocy metody dochodowej można określić stopę zwrotu uzyskaną na rynku pracy dzięki edukacji i pozyskanych klasyfikacji (Sikorska 2011). 
Tabela 2. Pomiar kapitału ludzkiego w badaniach mikro i makroekonomicznych

\begin{tabular}{|c|c|c|}
\hline Metody & Badania mikroekonomiczne - jednostka & Badania makroekonomiczne - populacja \\
\hline Wynikowa & $\begin{array}{l}\text { Cechy demograficzne: } \\
\text { - struktura wieku (\%), } \\
\text { - poziom wykształcenia (\%) } \\
\text { - migracje } \\
\text { Cechy społeczne: } \\
\text { - osiągnięcia szkolne } \\
\text { - liczba lat nauki, } \\
\text { - znajomość języków obcych } \\
\text { Stan zdrowia: } \\
\text { - długość życia } \\
\text { - choroby cywilizacyjne } \\
\text { Kompetencje społeczne: } \\
\text { - aktywność w organizacjach } \\
\text { pozarządowych } \\
\text { Umiejętność korzystania z ICT: } \\
\text { - obsługa komputera } \\
\text { - znajomość programów }\end{array}$ & $\begin{array}{l}\text { Cechy demograficzne: } \\
\text { - przyrost naturalny (\%o), } \\
\text { - dzietność (\%o), umieralność (\%o), } \\
\text { - przyrost rzeczywisty } \\
\text { Cechy społeczne: } \\
\text { - analfabetyzm (\%) } \\
\text { Stan zdrowia: } \\
\text { - zdrowotność, } \\
\text { - długość życia w momencie narodzin } \\
\text { Kompetencje społeczne: } \\
\text { - organizacje pozarządowe } \\
\text { Syntetyczne wskaźniki kapitału ludzkiego } \\
\text { Użytkownicy internetu: } \\
\text { - udział gospodarstw z dostępem do inter- } \\
\text { netu (\%) }\end{array}$ \\
\hline Kosztowa & $\begin{array}{l}\text { Koszty własne poniesione na naukę, szkole- } \\
\text { nie i zdrowie }\end{array}$ & $\begin{array}{l}\text { Wydatki publiczne na edukację (\% PKB), } \\
\text { zdrowie (per capita), informatyzację (\% PKB) }\end{array}$ \\
\hline Dochodowa & $\begin{array}{l}\text { Stopa zwrotu uzyskana na rynku pracy, } \\
\text { wysokość dochodów, zarobków w zależności } \\
\text { od wykształcenia i wieku }\end{array}$ & $\begin{array}{l}\text { Stopa zwrotu z wydatków na kształcenie } \\
\text { i edukację oraz zdrowie }\end{array}$ \\
\hline
\end{tabular}

Źródło: opracowano na podstawie: M. Dudek i P. Chmieliński (2011).

\section{Zmiany w zasobach i jakość kapitału ludzkiego}

Oceny realizacji celu głównego Programu Operacyjnego Kapitał Ludzki Poprawa jakości kapitału ludzkiego i zwiększenie spójności społecznej dokonano na przykładzie obszarów wiejskich Polski północnej i zachodniej oraz Niemiec wschodnich.

W latach 2002-2010 r. na obszarze Polski północnej i zachodniej nastąpił wzrost liczby ludności z 11012200 do 11302 329, tj. o 2,6\%, co stanowiło 28,8\% ogółu ludności kraju. Średnio w ciągu roku wzrost ludności wynosił około $2 \%$. W Polsce w tym samym czasie liczba ludności zmalała o 0,05\% (GUS). Przebieg trajektorii liczby ludności wiejskiej Polski północnej i zachodniej wskazuje na stabilny rozwój ludności (ryc. 1). Na początku lat dwutysięcznych nastąpił gwałtowny wzrost liczby ludności na obszarach wiejskich Polski północnej i zachodniej, po czym spadek do 2006 r., kiedy to nastąpiły perturbacje związane ze słabnącą dynamiką rozwoju demograficznego przełomu XX i XXI w., a następnie monotoniczny wzrost ze stopniowo słabnącą jego dynamiką. Przebieg trajektorii przedstawiającej liczbę ludności Niemiec wschodnich charakteryzuje się ciągłym spadkiem od początku lat dwutysięcznych do 2010 r. Tempo spadku utrzymuje się średnio na poziomie około $1 \%$ w skali roku.

Wzrost liczby ludności analizowanego obszaru Polski był rezultatem głównie przyrostu naturalnego, który w latach 2002-2010 wyniósł 56471 osób. W 2010 r. w Polsce północnej i zachodniej zanotowano dodatni przyrost naturalny (22 867 osób). Wyjątek stanowią dwa województwa opolskie (-796) i dolnośląskie (-10), w których liczba urodzeń nie zrekompensowała ogólnej liczby zgonów. Dodatkowo w województwie opolskim ujemne salda migracji wewnętrznych (-575) i zagranicznych (-2430) przyczyniły się do ubytku rzeczywistego ludności. Przyrost rzeczywisty w województwie dolnośląskim zrekompen- 
sowany został dodatnim saldem migracji wewnętrznych (1732), natomiast ujemne saldo migracji wewnętrznych w województwach warmińsko-mazurskim, pomorskim i lubuskim zrekompensowane zostało przez dodatni przyrost naturalny (tab. 3).

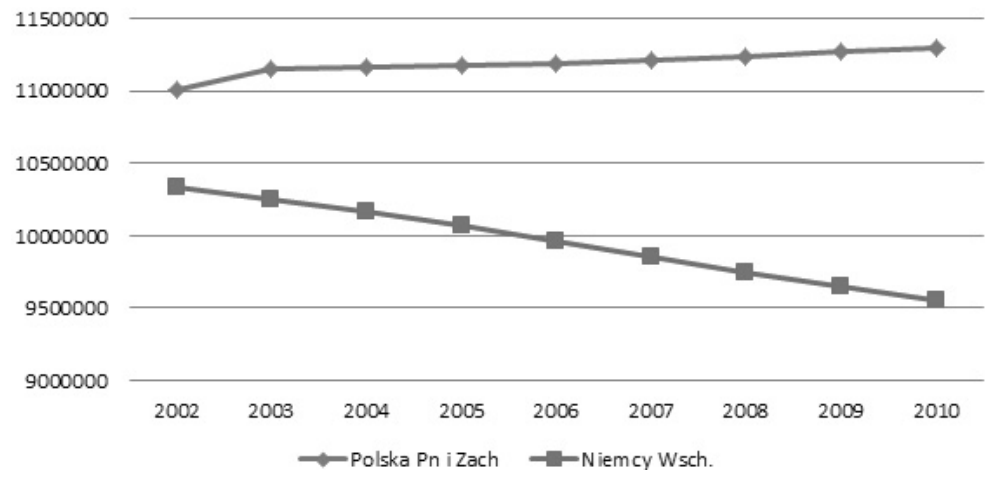

Ryc. 1. Zmiany liczby ludności na obszarach wiejskich Polski północnej i zachodniej oraz Niemiec wschodnich w latach 2002-2010

Źródło: opracowanie własne na podstawie: GUS, Statistisches Jahrbuch Deutschland.

Change of population number in rural areas of Northern and Western Poland and East Germany in 2002-2010 Source: own elaboration based on: CSO, Statistisches Jahrbuch Deutschland.

Tabela 3. Bilans ludności na badanym obszarze w 2010 r.

\begin{tabular}{|c|c|c|c|c|c|c|c|c|c|}
\hline \multirow{2}{*}{$\begin{array}{l}\text { Województwo/ } \\
\text { kraj związkowy }\end{array}$} & \multirow{2}{*}{$\begin{array}{l}\text { Ludność } \\
\text { ogółem }\end{array}$} & \multicolumn{2}{|c|}{$\begin{array}{l}\text { Przyrost } \\
\text { naturalny }\end{array}$} & \multicolumn{2}{|c|}{$\begin{array}{l}\text { Saldo migracji } \\
\text { wewnętrznych }\end{array}$} & \multicolumn{2}{|c|}{$\begin{array}{l}\text { Saldo migracji } \\
\text { zagranicznych }\end{array}$} & \multicolumn{2}{|c|}{$\begin{array}{l}\text { Przyrost/uby- } \\
\text { tek rzeczywisty }\end{array}$} \\
\hline & & liczba & $\%$ & liczba & $\%$ & liczba & $\%$ & liczba & $\%$ \\
\hline Lubuskie & 767931 & 1225 & 1,60 & -326 & $-0,42$ & -129 & $-0,16$ & 770 & 1,00 \\
\hline Wielkopolskie & 2617491 & 9247 & 3,53 & 5178 & 1,98 & -121 & $-0,05$ & 14304 & 5,46 \\
\hline Pomorskie & 1138759 & 1245 & 1,09 & -635 & $-0,56$ & 9 & 0,00 & 619 & 0,54 \\
\hline Dolnośląskie & 2056929 & -10 & 0,00 & 1732 & 0,84 & -532 & $-0,25$ & 1190 & 0,58 \\
\hline Opolskie & 902875 & -796 & $-0,88$ & -575 & $-0,64$ & -1059 & $-1,17$ & -2430 & $-2,69$ \\
\hline Kujawsko-Pomorskie & 1292383 & 2269 & 1,76 & 968 & 0,75 & -93 & $-0,07$ & 3144 & 2,43 \\
\hline Pomorskie & 1401232 & 7227 & 5,16 & 4027 & 2,87 & -124 & $-0,08$ & 11130 & 7,94 \\
\hline Warmińsko-Mazurskie & 1124729 & 2460 & 2,19 & -2073 & $-1,84$ & 100 & 0,08 & 487 & 0,43 \\
\hline $\begin{array}{l}\text { Polska północna } \\
\text { i zachodnia }\end{array}$ & 11302329 & 22867 & 2,02 & 8296 & 0,73 & -1949 & $-0,17$ & 29214 & 2,58 \\
\hline Brandenburgia & 2112168 & -8458 & $-4,00$ & -1764 & $-0,84$ & 1719 & 0,81 & -8503 & $-4,03$ \\
\hline Meklemburgia & 1122413 & -4409 & $-3,93$ & -6298 & $-5,61$ & 1301 & 1,16 & -9406 & $-8,38$ \\
\hline Saksonia & 2860288 & -15241 & $-5,33$ & -14273 & $-4,99$ & 365 & 0,12 & -29149 & $-10,19$ \\
\hline Saksonia Anhalt & 1783612 & -11416 & $-6,40$ & -10666 & $-5,98$ & 1584 & 0,88 & -20498 & $-11,49$ \\
\hline Turyngia & 1678635 & -8146 & $-4,85$ & -7263 & $-4,33$ & 1346 & 0,80 & -14063 & $-8,38$ \\
\hline Niemcy wschodnie & 9557116 & -47670 & $-4,90$ & -40264 & $-4,35$ & 6315 & 3,77 & -81619 & $-8,49$ \\
\hline
\end{tabular}

Źródło: obliczenia na podstawie: stat.gov.pl oraz stat.de 
W przeciwieństwie do Polski na obszarach wiejskich Niemiec wschodnich w latach 2002-2010 zaobserwowano spadek liczby ludności z 10340808 do 9 557116, tj. o 7,6\%. Podobnie w całych Niemczech liczba ludności zmalała o 1\%. Duży wpływ na spadek liczby ludności we wschodnich landach Niemiec miał utrzymujący się przez cały analizowany okres ujemny przyrost naturalny oraz ujemne saldo migracji. Obecna sytuacja demograficzna Niemiec wschodnich to efekt tzw. Wendeknick, tj. zmian polityczno-gospodarczych po 1990 r. (Grundmann 1998). Na obszarach wiejskich wschodnich landów od początku lat 90. utrzymuje się zjawisko depopulacji. Otwarcie granicy po 45 latach „żelaznej kurtyny" wywołało niespotykane wcześniej na taką skalę ruchy migracyjne ludności do zachodnich krajów związkowych. W strukturze wieku osób migrujących przeważały kobiety młode (w grupie wiekowej 18-32 lata), co wpłynęło znacząco na spadek urodzeń. W 2010 r. na obszarach wiejskich Niemiec wschodnich zanotowano ujemny przyrost naturalny $(-4,9 \%$ ) oraz ujemne saldo migracji wewnętrznych (-4,35\%o). Zjawisko depopulacji obserwuje się we wszystkich wschodnich landach Niemiec, w których w 2010 r. zanotowano ujemny przyrost rzeczywisty ludności. Najtrudniejsza sytuacja demograficzna występuje w dwóch krajach związkowych, w których ubytek rzeczywisty ludności wyniósł poniżej 10\%o, tj. w Saksonii Anhalt (-11,49\%o) oraz Saksonii (-10,19\%o). Spadek ludności w krajach saksońskich to efekt bardzo niskiego przyrostu naturalnego (odpowiednio:-6,40\%o i-5,33\%o) oraz ujemnego salda migracji (-5,98\% i-4,99\%o) (ryc. 2).

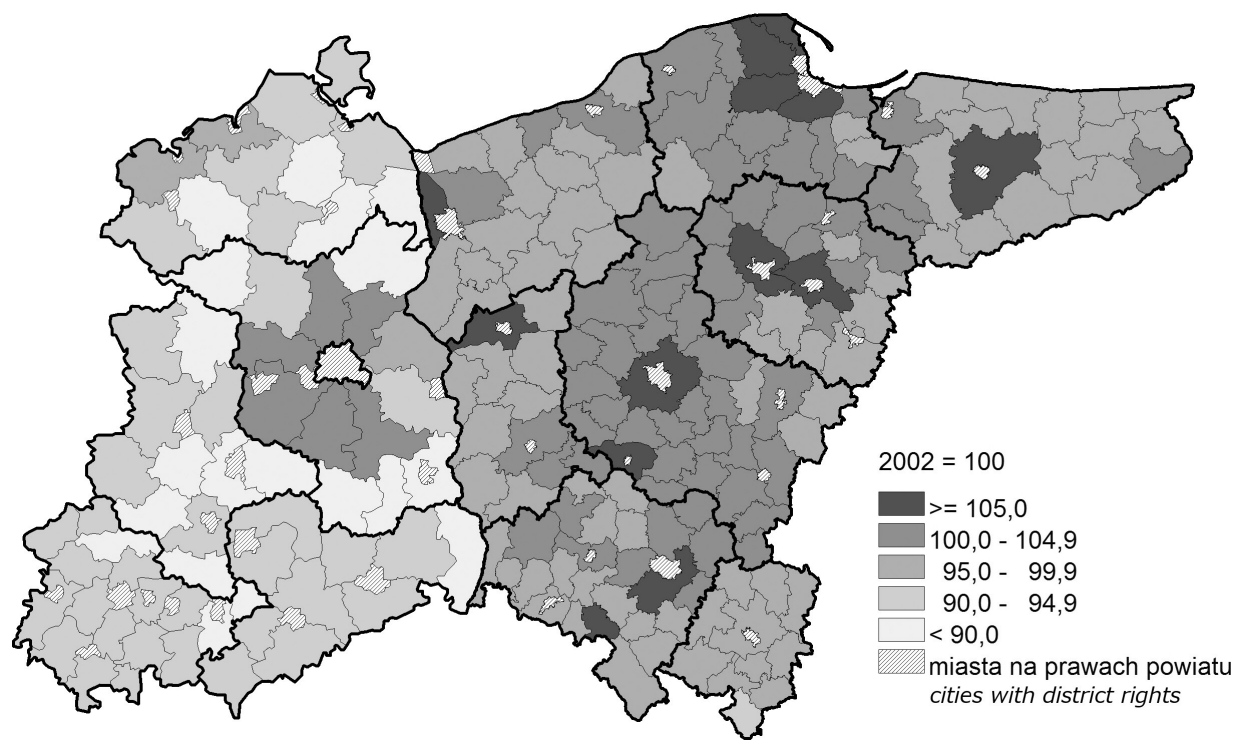

Ryc. 2. Dynamika zmian liczby ludności Polski północnej i zachodniej oraz Niemiec wschodnich w latach 2002-2010 Źródło: opracowanie własne na podstawie: GUS, Statistisches Jahrbuch Deutschland.

Change of population number in Northern and Western Poland and East Germany in 2002-2010

Source: own elaboration based on: CSO, Statistisches Jahrbuch Deutschland.

Ujemne saldo migracji w Meklemburgii $(-5,61 \%$ ) zrekompensowane zostało dodatnim saldem migracji zagranicznych $(+1,16 \%$ ), najwyższym we wschodnich Niemczech $(+1,16 \%$ o). W przeciwieństwie do Polski cechą charakterystyczną krajów związkowych jest dodatnie saldo migracji zagranicznych (+0,75\%o). Pomimo ujemnego przyrostu rzeczywi- 
stego ludności (-4,03\%o) w najlepszej sytuacji demograficznej znajdują się obszary wiejskie Brandenburgii, głównie z uwagi na zachodzące w bezpośredniej strefie oddziaływania metropolii Berlina procesy urbanizacji towarzyszące rozwojowi stolicy Niemiec.

Analiza wzajemnych relacji głównych składowych, tj. przyrostu naturalnego i salda migracji wykazuje duże zróżnicowanie przestrzenne rozwoju demograficznego, które jest odbiciem nierównego rozwoju społeczno-gospodarczego. W latach 2002-2010 nastąpiło obniżenie współczynnika przyrostu naturalnego w 48 powiatach Polski północnej i zachodniej oraz w 46 Niemiec wschodnich, co stanowiło odpowiednio 31,6\% i 85,2\% ogółu badanych powiatów. Zmniejszenie współczynników przyrostu naturalnego jest efektem wcześniejszych procesów depopulacji i następstwem procesów starzenia się ludności wiejskiej. Jest to zjawisko ogólnoeuropejskie charakterystyczne także dla krajów Europy Środkowo-Wschodniej, w tym również dla Niemiec wschodnich (ryc. 3).

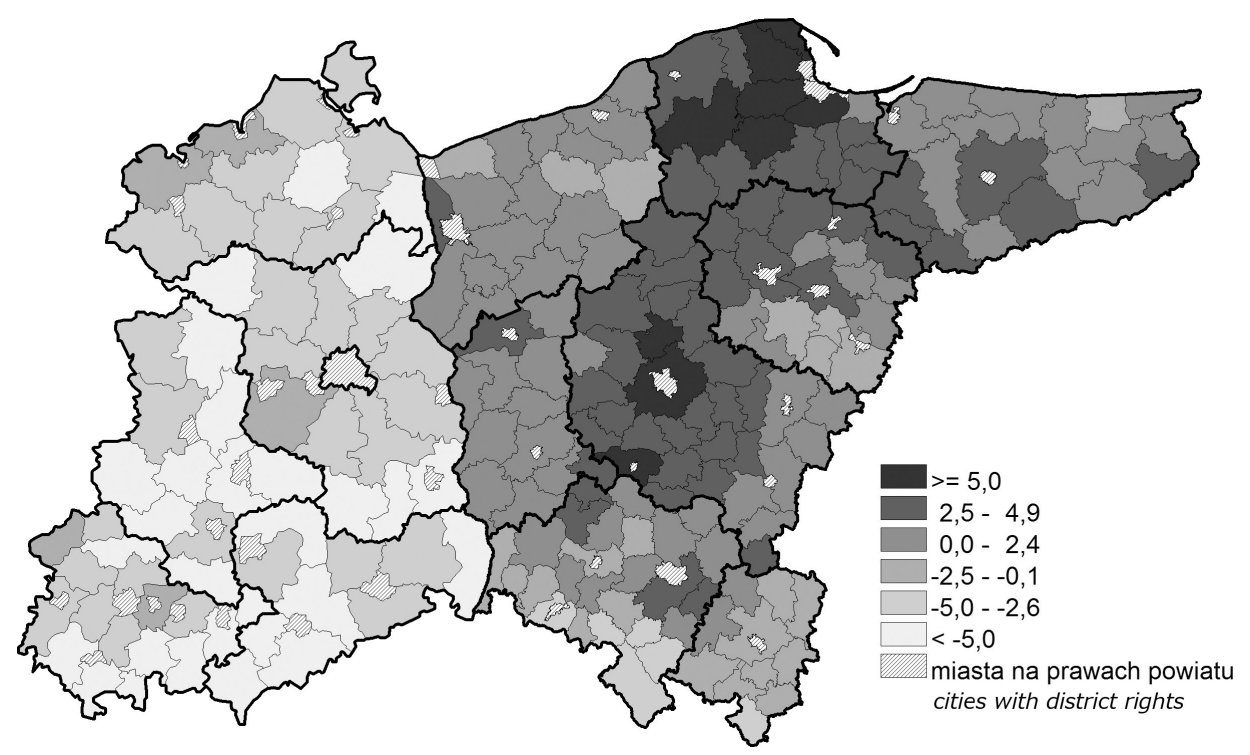

Ryc. 3. Przyrost naturalny Polski północnej i zachodniej oraz Niemiec wschodnich w 2010 r.

Źródło: opracowanie własne na podstawie: GUS, Statistisches Jahrbuch Deutschland.

Natural increase in Northern and Western Poland and East Germany in 2010

Source: own elaboration based on: CSO, Statistisches Jahrbuch Deutschland.

Współczynnik salda migracji wewnętrznych zmniejszył się w 68 powiatach w Polsce i 20 w Niemczech, co stanowiło 44,7\% i 37\% wszystkich badanych powiatów. W 13 powiatach w Polsce i dwóch w Niemczech nastąpiła zmiana wartości salda migracji z ujemnej na dodatnią, zaś w 11 w Polsce i jednym w Niemczech z dodatniej na ujemną (ryc. 4).

W 2010 r. wysokim dodatnim saldem migracji charakteryzowały się obszary wiejskie położone w strefie podmiejskiej miast wojewódzkich, np. w powiecie wrocławskim saldo migracji uległo podwojeniu do 23\%o, podobnie w gdańskim (19,5\%o) i puckim $(6,4 \%$ o). Zjawisko napływu ludności miejskiej na obszary wiejskie nasiliło się na początku XXI w., kiedy to zaczęto promować ekologiczny tryb życia, a firmy i korporacje budowlane oferowały wiejskie osiedla mieszkaniowe „pod lasem”, np. w okolicach Wrocławia, Trójmiasta czy Poznania. Ujemnym saldem migracji w dalszym ciągu charakteryzowały się wszystkie 


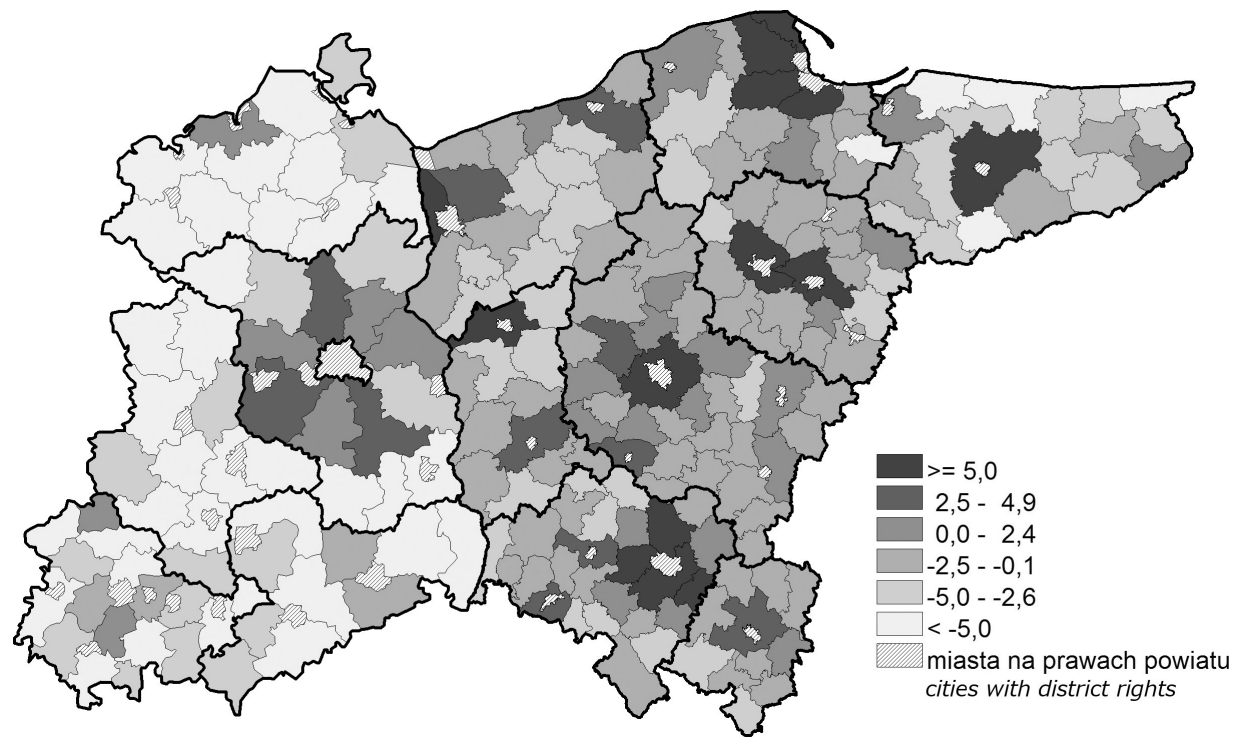

Ryc. 4. Saldo migracji Polski północnej i zachodniej oraz Niemiec wschodnich w 2010 r. Źródło: opracowanie własne na podstawie: GUS, Statistisches Jahrbuch Deutschland. Net migration rate in Northern and Western Poland and East Germany in 2010 Source: own elaboration based on: CSO, Statistisches Jahrbuch Deutschland.

powiaty położone przy północnej granicy Polski, przede wszystkim: braniewski (-8,3\%o), nidzicki $(-6,2 \%)$, bartoszycki $(-5,8 \%$ o), gołdapski $(-5,5 \%$ ) oraz powiaty przy granicy południowej z Czechami: kamiennogórski, wałbrzyski (po-3,3\%o), lubański (-2,0\%o) i kłodzki $(-1,8 \%$ o). Wyjątek stanowi powiat jeleniogórski, w którym zanotowano dodatnie saldo migracji $(+3,9 \%$ o).

Do oceny jakości kapitału ludzkiego przyjęto elementy społeczne: współczynnik obciążenia ekonomicznego (wyrażający relację liczby ludności w wieku przed i poprodukcyjnym do liczby ludności w wieku produkcyjnym) oraz stopę bezrobocia. W latach 2002-2010 wskaźnik obciążenia ekonomicznego $\left(W_{o e}\right)$ zmalał na obszarach wiejskich Polski północnej i zachodniej z 49 do 45, na skutek wchodzenia młodych roczników w wiek produkcyjny, wzrósł natomiast w Niemczech wschodnich z 43 do 54, na skutek zwiększenia udziału ludności w wieku poprodukcyjnym (ryc. 5).

Analiza przestrzenna wskaźnika obciążenia ekonomicznego wykazuje, że najwyższą jego wartość zanotowano w powiecie Gorlitz w Saksonii (61), najniższą zaś w powiecie polickim w województwie zachodniopomorskim (37) (ryc. 5). Cechą charakterystyczną obszarów wiejskich wschodnich Niemiec jest wysoki udział powiatów (83\%) z wysokim wskaźnikiem obciążenia ekonomicznego $\left(W_{o e}>50\right)$.

W 2010 r. stopa bezrobocia dla obszarów wiejskich północnej i zachodniej Polski wynosiła 9,8\% i w układzie przestrzennym wahała się od 2,2\% w powiecie poznańskim do 17\% w powiecie lipnowskim. Tak duża rozpiętość świadczy o nierównowadze w rozwoju społeczno-gospodarczym oraz dużym zróżnicowaniu przestrzennym rynku pracy na obszarach wiejskich. Wysoka stopa bezrobocia na początku lat dwutysięcznych (podobnie i lat 90.) utrzymywała się przede wszystkim w województwie warmińsko-mazurskim (21,8\%) i zachodniopomorskim (21\%). Do 2010 r. zaczęła maleć, na co wpłynęło niewątpliwie 
otwarcie rynków pracy dla Polaków w innych państwach UE. Dodatkowo nowe miejsca pracy mogły być sfinansowane z funduszy strukturalnych. W latach 2002-2010 bezrobocie w województwie zachodniopomorskim zmalało o połowę - z 21\% do 10,4\%, co wyraźnie wskazuje m.in. na wzrost miejsc pracy w tym regionie. Duże znaczenie dla rozwoju gospodarczego strefy przygranicznej z Niemcami miało wstąpienie Polski do UE w 2004 r. Przyczyniło się to do wzrostu liczby podmiotów gospodarczych z udziałem kapitału zagranicznego w tym regionie. W 2010 r. w układzie 8 województw najlepsza sytuacja na rynku pracy była w województwie wielkopolskim, w którym poziom stopy bezrobocia był najniższy i wynosił 6,9\%. Zróżnicowanie to wynika przede wszystkim z nierównomiernego poziomu urbanizacji i uprzemysłowienia obszarów wiejskich Polski.

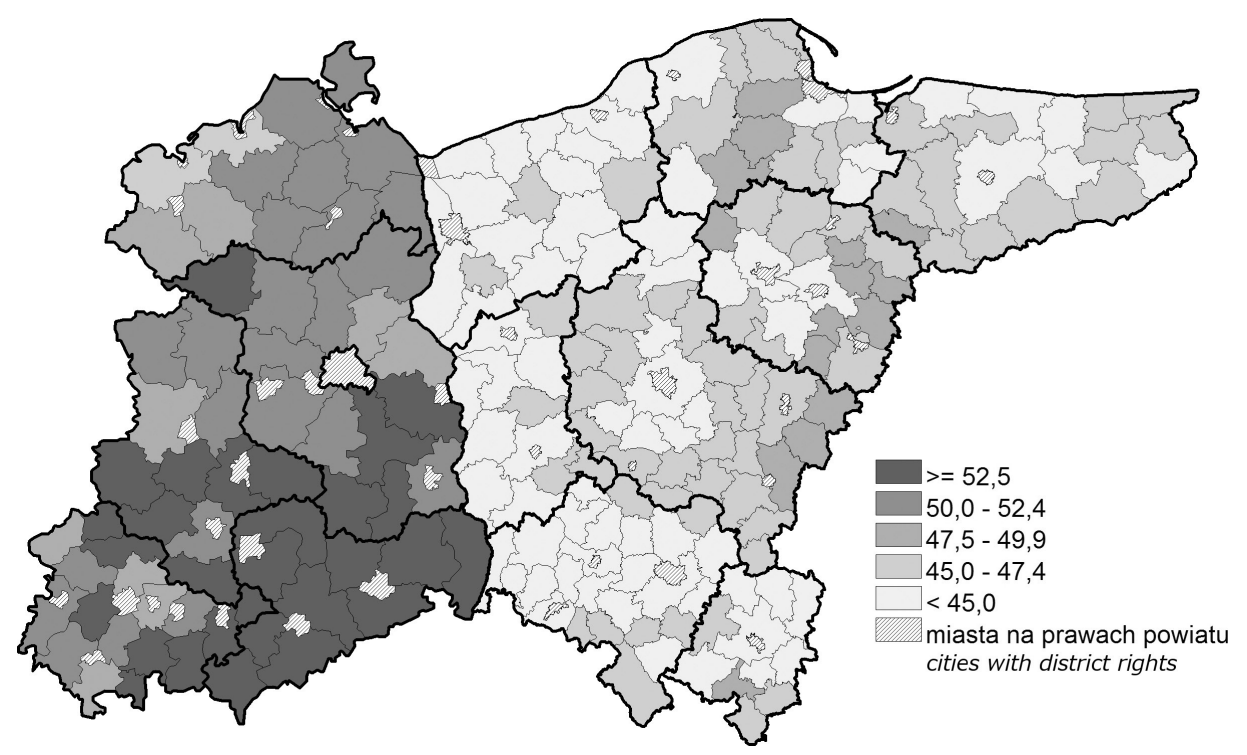

Ryc. 5. Wskaźnik obciążenia ekonomicznego $\left(W_{o e}\right)$ w Polsce północnej i zachodniej oraz Niemczech wschodnich w $2010 \mathrm{r}$.

Źródło: opracowanie własne na podstawie: GUS, Statistisches Jahrbuch Deutschland. Economic dependency ratio in Northern and Western Poland and East Germany in 2010 Source: own elaboration based on: CSO, Statistisches Jahrbuch Deutschland.

Analiza przestrzenna wykazuje, że najwyższe bezrobocie było na obszarach o dominacji sektora rolnego, w tym na terenach popegeerowskich, w powiatach: białogardz$\operatorname{kim}(16,7 \%)$, bartoszyckim (16,7\%), piskim $(16,2 \%)$, braniewskim $(15,2 \%)$, nowodworskim (14,6\%), elbląskim (14,4\%), szczycieńskim i lidzbarskim (po 14,1\%) oraz pyrzyckim (13,9\%). W trudnej sytuacji znajdowały się nadal obszary wiejskie, w których dominował wysoki udział zatrudnienia w przemyśle, tj. w powiecie grudziądzkim $(14,8 \%)$, włocławskim $(15,2 \%)$ (ryc. 6). Wysokie bezrobocie na tych terenach to efekt zwolnień grupowych chłoporobotników, tj. ludności zamieszkałej w gospodarstwach domowych z użytkowaniem gospodarstwa rolnego, z zakładów przemysłowych przeznaczonych do likwidacji. Najniższe bezrobocie zaobserwowano na terenie powiatów położonych w sąsiedztwie wiodących pod względem przemian aglomeracjach Poznania (poniżej 3\%) oraz Wrocławia i Trójmiasta (poniżej 4\%). 


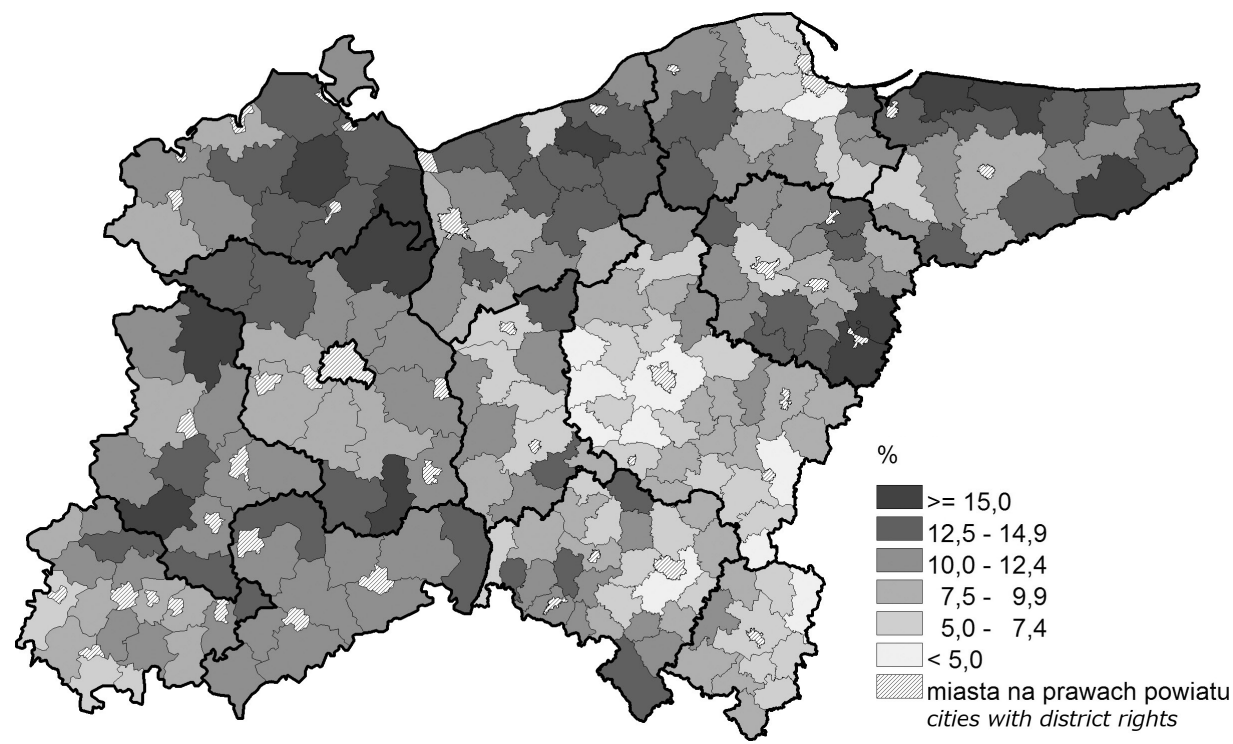

Ryc. 6. Bezrobocie na obszarach wiejskich w Polsce północnej i zachodniej oraz Niemczech wschodnich w 2010 r. (\%) Źródło: opracowanie własne na podstawie: GUS, Statistisches Jahrbuch Deutschland. Unemployment rate in rural areas of Northern and Western Poland and East Germany in 2010, (\%) Source: own elaboration based on: CSO, Statistisches Jahrbuch Deutschland.

\section{Wsparcie kapitału ludzkiego ze środków Unii Europejskiej w Polsce}

Kapitał ludzki stanowi kluczowy obszar oddziaływań w polityce Unii Europejskiej. Państwa członkowskie, realizując wytyczne strategii lizbońskiej, zobowiązały się do prowadzenia polityki zmierzającej do podniesienia jakości zasobów ludzkich. Ogromną rolę przykłada się do eliminacji dysproporcji w poziomie rozwoju miast i wsi.

W ramach Europejskiego Funduszu Społecznego (EFS) na poprawę jakości kapitału ludzkiego w perspektywie finansowej 2004-2006 przeznaczono ok. 1,9 mld euro. Największa alokacja EFS na poprawę jakości kapitału ludzkiego przypadła na Sektorowy Program Operacyjny Rozwój Zasobów Ludzkich (SPO RZL). W latach 2007-2013 zgodnie z Narodowymi Strategicznymi Ramami Odniesienia EFS w Polsce został ujęty w ramach Programu Operacyjnego Kapitał Ludzki (PO KL). Program ten jest największym w historii UE programem współfinansowanym z Europejskiego Funduszu Społecznego (EFS), na którego realizację przeznaczono 11429 mln euro. Głównym celem PO KL jest umożliwienie pełnego wykorzystania potencjału zasobów ludzkich poprzez „zmniejszenie obszarów wykluczenia społecznego” (Ocena... 2010). EFS wspiera rozwój zasobów ludzkich, zatrudnienie oraz integrację społeczną. Z pomocy skorzystało ponad 9 mln osób, tj. jedna czwarta wszystkich mieszkańców Polski (Sprawozdanie... 2013).

$\mathrm{Na}$ analizowanym obszarze północnej i zachodniej Polski największy udział w wydatkach na podnoszenie kapitału ludzkiego z EFS w latach 2004-2009 zanotowano w województwie dolnośląskim $(7,65 \%)$ i był on dużo niższy od największego udziału ogółem w Polsce przypadającego na województwo mazowieckie (22,06\%) (ryc. 7). 


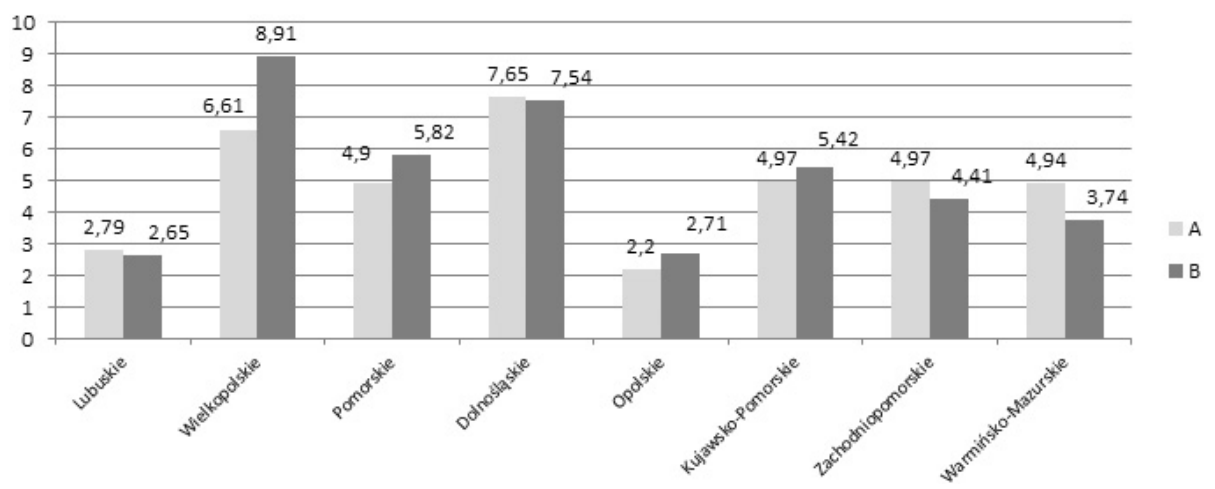

Ryc. 7. Udział województw Polski północnej i zachodniej w wydatkach na podnoszenie kapitału ludzkiego z EFS (A) oraz w liczbie ludności ogółem (B) w latach 2004-2009, (\%)

Źródło: opracowano na podstawie: Ocena... (2009).

Share of Northern and Western Poland voivodships expenditure on human capital from the ESF (A) and in total population (B) 2004-2009, (\%)

Source: own elaboration based on: Ocena...(2009).

Średnia wartość dofinansowania środków z EFS na 1 mieszkańca dla Polski wynosiła 198,75 zł. W ramach projektów ogólnokrajowych na jedną osobę przypadało ok. 72,1 zł dofinansowania z EFS. Za największego beneficjenta na analizowanym obszarze uważa się mieszkańców województw warmińsko-mazurskiego (167,39zł) i lubuskiego (133,52 zł) (ryc. 8).

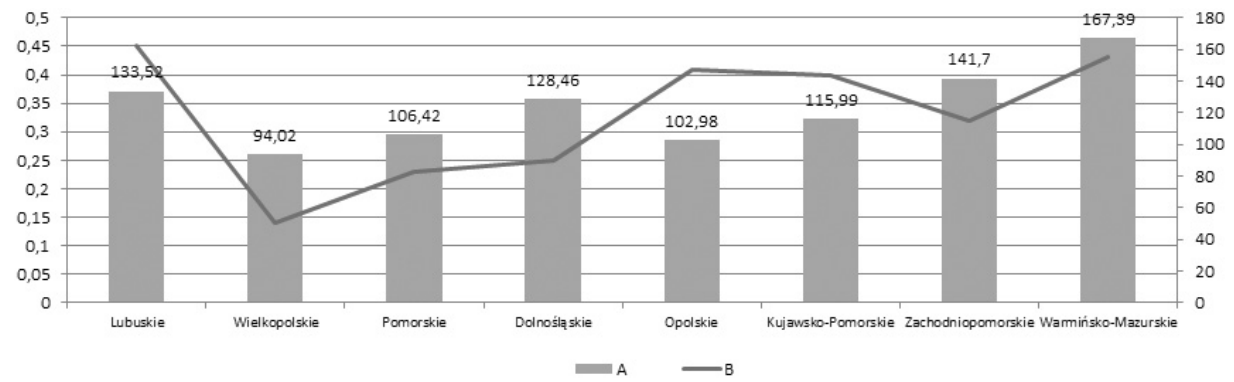

Ryc. 8. Wartość dofinansowania z EFS (A) i średnia wartość projektu per capita (B) w latach 2004-2009 (zł) Źródło: opracowano na podstawie: Ocena... (2009)

Funding from the ESF (A) and average project value per capita (B) in 2004-2009 (PLN)

Source: own elaboration based on: Ocena...(2009)

Zauważa się, że wyższe wydatki na rozwój zasobów ludzkich ponoszono w regionach o niższym poziomie kapitału ludzkiego. Najwyższa średnia wartość projektu per capita przypadała na województwo lubuskie $(0,45$ zł), a następnie warmińsko-mazurskie $(0,43$ zł) i opolskie $(0,41$ zł). 


\section{Zakończenie}

Przedmiotem badań były zmiany w kapitale ludzkim na obszarach wiejskich kształtujące się pod wpływem polityki regionalnej UE. Analiza porównawcza zmian demograficznych na obszarach wiejskich Polski północnej i zachodniej oraz Niemiec wschodnich pozwoliła na wyłonienie obszarów wzrostu kapitału ludzkiego oraz potencjalnych obszarów problemowych.

Wspólną cechą Polski i Niemiec jest utrzymujący się spadek ludności. W latach 20022010 doszło do pogłębienia się różnic międzyregionalnych pod względem stanu, dynamiki i struktury ludności. Szczególnie duże różnice widoczne są w strukturze wieku ludności, które niekorzystnie wpływają na wskaźnik obciążenia ekonomicznego. Nadal utrzymuje się historyczny podział na regiony "stare” i względnie „młode”. Polska i Niemcy należą do krajów europejskich, w których dostrzega się bipolarność regionalną procesów demograficznych. Oznacza to, że na analizowanym obszarze wyróżniono regiony charakteryzujące się wzrostem oraz spadkiem kapitału ludzkiego. W Polsce północnej i zachodniej obszary wzrostu kapitału ludzkiego położone są wokół miast wojewódzkich (Poznania, Gdańska, Wrocławia). Jednocześnie na terenie tych województw zaobserwowano największy udział w wydatkach na podnoszenie kapitału ludzkiego z EFS w latach 2004-2009. W obrębie miast wojewódzkich zaobserwowano napływ ludności z obszarów peryferyjnych oraz odpływ z miast do strefy podmiejskiej. Efektem odpływu ludności jest ujemne saldo migracji w strefie peryferyjnej, dodatnie zaś w strefie podmiejskiej. W Niemczech wschodnich obszary wzrostu kapitału ludzkiego występują w strefie „bliskiego kontaktu” lub „bezpośredniego oddziaływania” z metropolią Berlina oraz większymi aglomeracjami miejskimi. Zauważa się, że wraz ze wzrostem odległości od miast maleje aktywność demograficzna regionu, tj. maleje przyrost naturalny, występuje ujemne saldo migracji. Wyjątek stanowią obszary położone wzdłuż linii komunikacyjnych. Obszary te zyskują na tzw. rencie położenia. Ogólnie na obszarach wiejskich Polski północnej i zachodniej wystąpiła tendencja poprawy bilansu migracyjnego z-0,7\% do-0,3\% oraz wzrost współczynnika przyrostu naturalnego z 1,3\%o do 1,9\%o. Sytuacja demograficzna na obszarach wiejskich Niemiec wschodnich uległa pogorszeniu, tzn. nastąpił spadek współczynnika przyrostu naturalnego z-3,9 do-4,9\%o oraz $w$ dalszym ciągu utrzymuje się ujemne saldo migracji na poziomie -4,3\%o. Na analizowanym obszarze zmniejszeniu uległ proces depopulacji obszarów wiejskich charakterystyczny dla początkowej fazy transformacji ustrojowej.

Analiza porównawcza zróżnicowania regionalnego struktury zatrudnienia i bezrobocia w latach 2003-2010 wykazuje, że regiony o najwyższym poziomie bezrobocia to głównie obszary rolnicze, o dużym udziale gospodarstw wielkoobszarowych. Obszarami najniższego natężenia bezrobocia są tereny wiejskie województwa wielkopolskiego $(6,9 \%)$ i opolskiego (7,7\%) oraz kraju związkowego Turyngii (10,7\%). Powiaty o najniższym poziomie bezrobocia cechują się wysokim poziomem urbanizacji i uprzemysłowienia, przy stosunkowo wysokim udziale usług. Bezrobocie w Polsce północnej i zachodniej, podobnie jak w Niemczech wschodnich, stanowi nadal podstawowy problem społeczny utrudniający rozwój gospodarczy kraju.

Prezentowane badania przeprowadzone i sfinansowane zostały w ramach projektu naukowego Oddziaływanie instrumentów finansowych Unii Europejskiej na rozwój społeczno-gospodarczy obszarów wiejskich przyznanego przez Narodowe Centrum Nauki. 


\section{Literatura}

Bański J., Czapiewski K., 2008, Identyfikacja i ocena czynników sukcesu społeczno-gospodarczego na obszarach wiejskich, Zespół Badań Obszarów Wiejskich, IGiPZ PAN, Warszawa.

Becker G., 1962, Investm in Human Capitl: A Theortical Analysi, Journal of Political Economy, 70, s. 9.

Becker G.S., 1975, Human capital: a theoretical and empirical analysis, with special reference to education, University of Chicago Press, Chicago.

Becker G.S., Murphy K.M., Tamura R., 1990, Human capital, fertility, and economic growth, Journal of Political Economy, 98, 5, 2, s. 12-16.

Cahuc P., Zylberberg A., 2004, Labor economics, The Massachusetts Institute of Technology Press, Cambridge and London.

Cichy K., 2008, Kapitał ludzki i postęp techniczny jako determinanty wzrostu gospodarczego, Instytut Wiedzy i Innowacji, Warszawa.

Cichy K., Malaga K., 2009, Human Capital, Technological Progress and Economic Growth in Selected Countries of the European Union, Zeszyty Naukowe, Uniwersytet Ekonomiczny w Poznaniu, 112, s. 34-50.

Domański S.R., 1998, Kapitał ludzki, Stan i perspektywy, RSSG, Warszawa.

Domański S.R., 1993, Kapitał ludzki i wzrost gospodarczy, PWN, Warszawa.

Dudek M., 2008, Rola czynnika ludzkiego w rolnictwie indywidualnym na przykładzie gospodarstw emerytów i młodych rolników, IERiGŻ - PIB, Warszawa.

Dudek M., Chmieliński P., 2011, Znaczenie kapitału ludzkiego - uwagi teoretyczne, [w:] A. Sikorska (red.), Uwarunkowania rozwoju kapitału ludzkiego w rolnictwie i na obszarach wiejskich, IERiGŻ, Warszawa, s. 11-58.

Ekins P., Dresner S., Dahlstrom K., 2007, The four-capital method of sustainable development evaluation, European Environment, 18, Willey Inter Science, s. 63-80.

Fitz-Enz J., 2001, Rentowność Inwestycji w kapitał ludzki, Oficyna Ekonomiczna, Kraków.

Galor O., Moav O., 2004, From physical to human capital accumulation: inequality and the process of development, Review of Economic Studies, 71, 249, s. 1001-1026.

Grundmann S., 1998, Bevölkersungsentwicklung In Ostdeutschland, Demographische Strukturen und räumliche Wandlungsprozesse auf dem Gebiet der neuen Bundesländer, Leske, Budrich, Opladen.

Grzywacz W., Jaźwiński I., 2007, Współczesne uwarunkowania i tendencje polityki ekonomicznej, Wydawnictwo Naukowe Uniwersytetu Szczecińskiego, Szczecin.

Heffner K., Gibas P., 2013, Delimitacja przestrzenna obszarów wiejskich o słabym dostępie do usług publicznych w województwie lubuskim, Ekspertyza, Zielona Góra, 16 grudnia 2013.

Jabłoński Ł., 2010, Kapitał ludzki czynnikiem wzrostu gospodarczego w krajach OECD, Wiadomości Statystyczne, 8, s. 51-67.

Jezierska-Thöle A., Gwiaździnska-Goraj M., 2013, Zasoby pracy w gospodarstwach rolnych oraz problemy bezrobocia ukrytego w Północnej Polsce, Rocz. Nauk. Ekon. Agrobiz., Warszawa-Poznań-Kraków, 15, 5, s. 103-109.

Jezierska-Thöle A., Gwiaździńska-Goraj M., 2011, Zrównoważony rozwój społeczno-gospodarczy małych miast na podstawie endogenicznego potencjału regionu województw kujawsko-pomorskiego i warmińsko-mazurskiego, [w:] K. Heffner, T. Marszal (red.), Rewitalizacja, gentryfikacja i problemy rozwoju matych miast, Studia KPZK PAN, 86, Warszawa, s. 167-187.

Jezierska-Thöle A., Kluba M., 2012, Einfluss der EU-Mitgliedschaft Polens auf die demographischen Veränderungen in der polnischen Landwirtschaft, [w:] E. Bojenko-Izdebska (red.), Gemeinsame Wege? Transformation in Deutschland und Polen, OEZ-Verlag, Berlin, s. 121-134. 
Keeley B., 2007, Human capital. How what you know shapes your life, OECD Insights, Paryż.

Kozioł W., 2011, Human capital dynamics: essence and determinants, The Małopolska School of Economics in Tarnów Research Papers Collection, ISSUE 1/2011.

Krzyżanowska K. (red.), 2012, Społeczno-ekonomiczne determinanty rozwoju obszarów wiejskich, Wydawnictwo SGGW, Warszawa.

Kunasz M., 2003, Znaczenie kapitału ludzkiego jako składnika kapitału intelektualnego, [w:] K. Piech, M. Kulikowski (red.), Przedsiębiorczość: szansq na sukces rzqdu, gospodarki, przedsiębiorstw i społeczeństwa, Instytut Wiedzy, Warszawa, s. 285-298.

Kwon D.B., 2009, Human capital and its measurement, referat wygłoszony na Trzecim Forum OECD "Statistics, knowledge and policy. Charting progress, building visions, improving life", Busan, Republika Korei, październik 2009, [http://oecd.org, 26.08.2011].

Lucas R.E., 1988, On the mechanics of economic development, Journal of Monetary Economics, 22, S. 3-42.

Mincer J., 1958, Investment in human capital and personal income distribution, Journal of Political Economy, 66, 4, The University of Chicago Press, Chicago.

Nelson R., Phelps E., 1966, Investm in Humans, Technolgia Difuson, and Econmi Grwth, American Economic Review, 56, s. 69-75.

Nelson R., Winter S., 2009, An evolutionary theory of economic change, Harvard University Press. Ocena wpływu realizacji interwencji wspótfinansowanych z EFS na podniesienie jakości zasobów ludzkich, 2010, Instytut Badań Strukturalnych, Ministerstwo Rozwoju Regionalnego, Warszawa.

OECD, 2005, Policy Issues and Recent Policy Developments Concerning SMEs and Entrepreneurshi, W OECD SME and Entrepreneurship Outlook.

Poczta W., Pawlak K., Kiryluk-Dryjska E., Siemiski P., 2007, Perspektywy polskich gospodarstw rolnych w Europejskim Modelu Rolnictwa, Rocz. Nauk. Ekon. Agrobiz. Warszawa-Poznań-Kraków.

Romer P., 1986, Increasing returns and long run growth, Journal of Political Economy, 94, s. $1002-1037$.

Romer P., 1990, Endogenous technological change, Journal of Political Economy, 98, s. 71-102.

Schultz T., 1961, Investm in Human Capitl, American Economic Review, 51, s. 1-17.

Sikorska A., (red.), 2011, Uwarunkowania rozwoju kapitału ludzkiego w rolnictwie i na obszarach wiejskich, IERiGŻ, Warszawa.

Sprawozdanie z wdrażania Programu Operacyjnego Kapitał Ludzki 2007-2013, Warszawa, czerwiec 2014 r.

Stanny M., 2011, Typologia wiejskich obszarów peryferyjnych pod względem anatomii struktury społeczno-gospodarczej, Wieś i Rolnictwo, 2 (151), s. 60-75.

Stanny M., 2013, Przestrzenne zróżnicowanie rozwoju obszarów wiejskich w Polsce, IRWiR, PAN, Warszawa.

Tkaczyński J., Willa R., Świstak M., 2008, Fundusze Unii Europejskiej 2007-2013. Cele, działania, środki, Wyd. Uniwersytetu Jagielońskiego, Kraków.

Uzawa H., 1965, Optimu Technial Cgein Agreativ Modelf Econmi Growth, International Economic Review, 6, s. 18-31.

Weisbrod B., 1962, Education and Investment in Human Capital, Journal of Political Economy, 70, s. $106-123$.

Wilkin J., 2012, Polska wieś 2012 - główne tendencje, zjawiska i problemy, Synteza raportu, [w:] J. Wilkin i I. Nurzyńska (red.), Polska wieś 2012, Raport o stanie wsi, Wydawnictwo Scholar, Warszawa, s. 9-30.

Wilkin J., 1998, Bariery edukacyjne i informatyczne, [w:] M. Kłodziński, J. Wilkin, (red.), Rozwój obszarów wiejskich w Polsce, FAPA, Warszawa. 


\section{Summary}

The purpose of this article is to present changes in capability and quality of human capital and to assess the impact of implementing ESF co-financed interventions in improving the quality of human resources. An important element of the work was the genesis of research in the subject of human capital as one of the most important economic resources. For this purpose, a review of economic theories regarding the importance and role of human capital in socio-economic development of the country and region was conducted. The areas of study comprised Northern and Western Poland and East Germany. To evaluate the quality of human capital demographic (population growth, migration) and social elements (employment, economic dependency ratio, unemployment) were considered. Conducted research allowed for identification of rural human capital growth areas and potential problem areas. 
http://rcin.org.pl 